\title{
Immune Dysfunction and Cytokine Production in Hemodialysis
}

\author{
Could They Be Lessened by Vitamin E-Coated Dialyzer Membrane?
}

\author{
Massimino Senatore ${ }^{c}$ Pasqualina Cecere ${ }^{a}$ Patrizia Colombo ${ }^{a}$ \\ Luigia Costantinia Oliviero Filibertia Giovanna Piccinia Carla Peona ${ }^{a}$ \\ Michele Buemi $^{b}$ Antonio Nicolettic Giuseppe Rizzuto ${ }^{c}$ \\ aServizio di Nefrologia e Dialisi, Ospedale S. Andrea, Vercelli; bll Cattedra di Nefrologia, Università di Messina; \\ 'Servizio di Dialisi, Presidio Ospedaliero S. Giovanni in Fiore, Crotone, Italia
}

\section{Cytokine Pattern in Uremia}

Most uremic patients in dialysis therapy develop an immunodeficiency characterized clinically by frequent infectious complications and impaired response to vaccinations [1]. This became evident in the early period of hemodialysis treatment when endemic outbreaks of hepatitis B threatened dialysis centers [2]. Vaccination results against hepatitis $\mathrm{B}$, in dialysis patients, are disappointing: low results are also documented for most other types of vaccinations in these patients, such as influenza [3], tetanus [4] or diphteria [5]. There is an only exception in using vaccination containing polysaccharide antigens like pneumococcus [6]. Polysaccharide antigens are recognized by $B$ cells on their own, but for recognition of other antigens, B cells need specific T-cell help: these observations indicate that the major defects appear to be in cellmediated immunity [7-9] and in particular correlated to T-cell rather than B-cell function [10].

In normal conditions, in response to antigens, naive CD4+ $T$ cells differentiate into effector $T$ helper $(\mathrm{Th})$ cells. Based on their pattern of cytokine production and their functional responses, Th cells can be subdivided into those that participate in cell-mediated immune responses such as delayed type of hypersensitivity reactions and macrophage activation (Th1 subset) and those releasing cytokines that induce B cells to secrete antibodies (Th2 subset). Several factors are known to polarize the differentiation of Th cells into either Th1 or Th2 direction, including the co-stimulatory action of antigen presenting cells (APCs), the cytokine environment, altered peptide ligands and the antigen dose. In particular, Th1 are characterized by elevated secretion of interleukin (IL)-2, transforming growth factor- $\beta$ (TGF- $\beta$ ) and interferon- $\gamma$ (IFN- $\gamma$ ), thereby activating cytotoxic T lymphocytes and macrophages. Moreover, IFN- $\gamma$ suppresses Th2 which induces humoral immunity. The Th2 subset of CD4+ T cells preferentially secretes IL-4, IL-5, IL-6 and IL-10 [1113], stimulating the proliferation of mast cells and eosinophils as well as the production of immunoglobulins and IL-10 which may suppress the Th1-induced cell-mediated immunity $[14,15]$. In general, Th1 cytokines promote Th1 and inhibit Th2 activities and vice versa. Th1 and Th2 responses should, therefore, be stable [16].

Chronic renal failure induces a clinical state of immunodeficiency in most patients: immune defects may be caused by uraemic state itself and by a direct consequence of dialytic therapy $[17,18]$.

Dialysis has been associated with acute changes in the complement activation status, granulocyte markers, macrophage function, T-cell activation and the release of various pro-inflammatory cytokines. Although the physiolog-

\begin{tabular}{ll}
\hline KARGER & ○ 2002 S. Karger AG, Basel \\
Fax +41 61 306 12 34 & 0028-2766/02/0924-0758\$18.50/0 \\
$\begin{array}{l}\text { E-Mail karger@karger.ch } \\
\text { www.karger.com }\end{array}$ & $\begin{array}{l}\text { Accessible online at: } \\
\text { www.karger.com/journals/nef }\end{array}$
\end{tabular}

\author{
Massimino Senatore \\ Piazza dei Bruzi, 5 \\ I-87100 Cosenza (Italy) \\ Tel. +390984 71229, Fax +390984 939661, E-Mail senatorem@yahoo.com
}


ic role of circulating cytokines is unknown, it is conceivable that a proinflammatory milieu characterized by high cytokine plasma levels may infuence specific and tightly regulated cellular processes in leukocytes, inducing an inappropriate cellular and/or humoral immune response.

In dialysis patients, both Th lines of differentiation show reduced activation, which is accompanied by the low production of IL-2, a cytokine uniformly involved in the expansion of these lines. However, chronic renal failure induces a bias of differentiation toward the Th1-type cells. This defect most probably results from an abnormality in the regulation of IL-12, the APC-derived cytokine that is primary inducer of the Th1 cells [19]. This mediator is overexpressed by monocytes from hemodialysis patients and this might thus explain the bias toward Th1 differentiation [20].

In addition, another evidence that the primary defect is localized in providing insufficient costimulatory signaling from the APC cells is given by their reduced expression of B7-2 (CD86) in hemodialysis patients that normally binds CD28 on T cells [21]. The expression of B7-1 (CD80) and the primary signaling molecule human lymphocyte antigen class II is not affected. Interestingly, the B7 molecules transmit signals that directly act on the induction of IL-2 [22].

The studies of Daichou et al. [23] and Donati et al. [24] showed that in uremia, T-cell proliferation is associated with the downregulation of IL-2 synthesis by lymphocytes and the induction of an abnormal state of lymphoblast activation that is further enhanced following chronic hemodialysis (HD). In chronic renal failure there is a decreased number of CD4+ $[25,26]$ and an increased proportion for CD8+ cells [24, 27], but the absolute numbers of CD8+ are supposedly low $[28,29]$ or unchanged [30, 31 ]. As $T$ cells produce IL-2, the decreased number of CD4+ cells partly explains the suppressed IL-2 production [32]. A single in vitro study [33] has demonstrated that the production of IL-2 is similar in T cells from patients and controls. However, in vitro mitogen-stimulated human peripheral blood lymphocytes release IL-2R that can bind IL-2 and inhibit IL-2-dependent cell proliferation [34]. In uremic patients, IL-2R plasmatic levels increase $[35,36]$ and may attenuate the availability of IL2 by binding to it and may further contribute to the immune system defects associated with uremia in vivo $[37,38]$.

Another cytokine affected by uremia is IFN- $\gamma$ but the data are controversial. While some authors confirm nonsignificant differences in IFN- $\gamma$ production between healthy controls and HD patients [39, 40], Daichou et al.

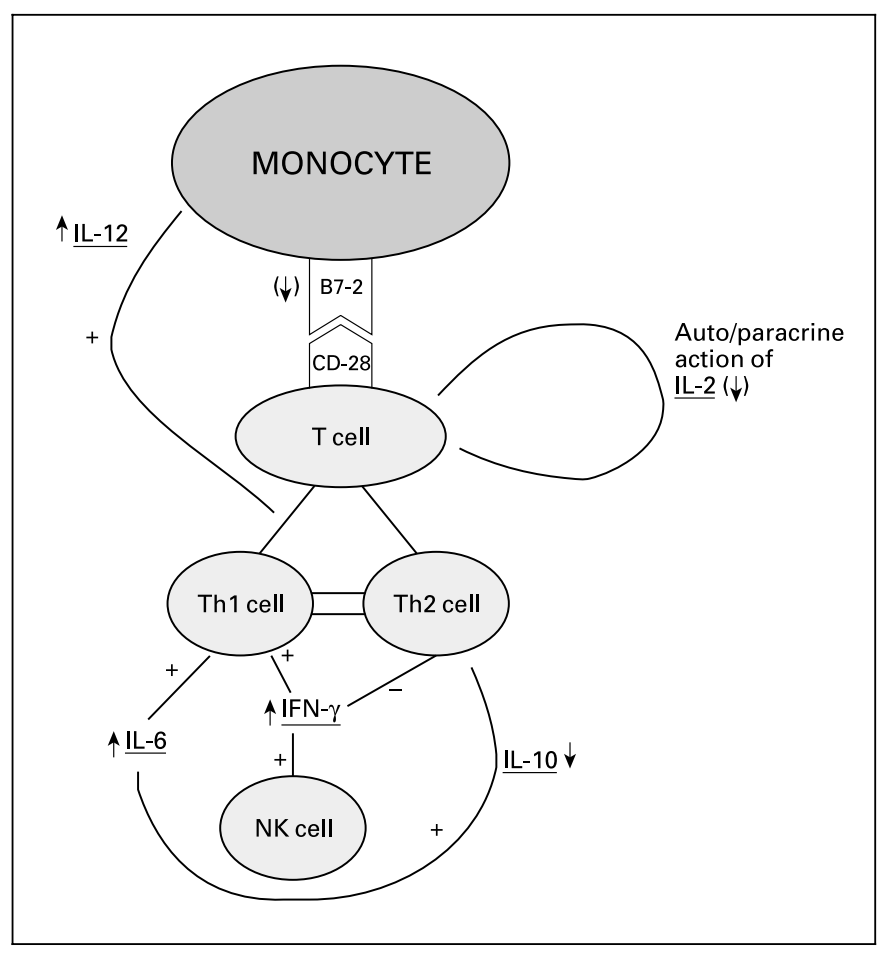

Fig. 1. Immune dysfunction and cytokine pattern in uremia.

[23] underline the IFN- $\gamma$ production is increased in uremia. IFN- $\gamma$ is produced by Th 1 cells and NK cells. IFN- $\gamma$ selectively inhibits Th2 cell proliferation [41] and IL-10 mRNA [42], while IL-10 inhibits cytokine synthesis by Th1 cells [43]. Moreover, IFN- $\gamma$ produced by Th1 stimulates CD8+ suppressor/cytotoxic lymphocytes and CD16+ NK cells [44]. IL-12 is capable to stimulate the synthesis of IFN- $\gamma$ by NK cells: this stimulation leads to macrophage activation which among numerous responses includes increased cytokine synthesis, ultimately leading to even more NK cell IFN- $\gamma$ production [45]. Moreover, IL-12 plus IFN- $\gamma$-inducing factor (IL-18) act on Th1 cells and induce the secretion of IFN- $\gamma$ [46].

Considered the different behaviours of IL- 2 and IFN- $\gamma$ in uremia, Eszter et al. [47] found that their genes are not coordinately regulated at the post-transcriptional level but the stability of IFN- $\gamma$ mRNA is modulated by IL- 12 . This selective control leads to increased IFN- $\gamma$ production. Sester et al. [20] have demonstrated in vitro that the production of IL-12 per single cell is not altered, thus leaving two main factors contributing to increased levels of IL-12. One factor is that HD patients have increased numbers of circulating monocytes [48]. Secondly, among the uremic patients, a higher percentage is capable of producing IL-12 [24]. Overproduction of IL-12 is a phenome- 
non well in line with other observations on dysregulated cytokine production in dialysis patients, such as IL-6, TNF $\alpha$ and IL- $1 \beta$.

Moreover, increased IL-6 levels are due to increased percentage of cytokine-producing cells (whereas the expression per single cell equals that of control cells) and to the patient's ability to upregulate IL-10 which controls the overproduction of IL-6 [49]. IL-10 acts as a counter-regulatory mechanism by limiting proinflammatory responses. Secretion of IL-6 is followed by the induction of IL-10 within a few hours. So the inflammation is limited and can be shut down again. The dialysis patients who secrete high amounts of IL-10 can reduce the overproduction of cytokines (fig. 1).

\section{Vitamin E-Coated Dialyzer Membrane}

Many factors may influence the immune system in dialysis: type of dialytic treatment, membranes, dialytic age, $\mathrm{Kt} / \mathrm{V}$, malnutrition, underlying nephropathy but, among these, the use of more compatible dialyzers or membranes that actively modify immune function such as dialyzers coated with vitamin E seems to give good results [50]. It is well known that hemodialysis membrane materials have been demonstrated to activate the oxidative metabolism of polymorphonuclear (PMN) cells and monocytes/macrophages [51, 52]. Activated leukocytes generate oxygen free radicals (OFR) that react strongly against a wide spectrum of biomolecules [53], resulting in a series of cytotoxic effects commonly described as 'oxidative stress'. In addition, the dialyzer induces, both directly and indirectly, the cytokine production during hemodialysis through complement activation. This control is regulated at a gene level: adherence to dialysis membrane induces selective mRNA expression of monocyte mediators and proto-oncogene [54, 55]. Furthermore, several studies support the hypothesis that terminal complement complex (TCC) generation may have a potential role in activating mononuclear cells [56]. TCC can affect cell metabolism and constitute a potent signal for activation of monocytes to produce inflammatory mediators such as TNF- $\gamma$ and IL-6 [55].

Cytokine activation may be induced also by bacterialderived material, for example lipopolysaccharide, contaminating the dialysate and able to cross the membrane [57].

In an attempt to increase the quality of HD filters, vitamin E-coated multilayer hemodialysis filter was recently produced with the two goals of obtaining an improvement in biocompatibility and a specific protection against OFR $[51,58]$. A growing body of evidence points to a defective antioxidant/prooxidant balance, a pathogenic factor in some HD-related side effects such as: anemization, defective immunological and coagulative functions, accelerated atherosclerosis and aging, $\beta_{2}$-microglobulin amyloid arthropathy and cancer onset.

In this context, the lack of antioxidant protection, and in particular a deficit of vitamin $\mathrm{E}$, has long been a subject of investigation [59]. At the same time, an increased prooxidant stimulus from PMN activated by the bioincompatibility of HD materials has been suggested [60], but is not yet completely understood.

Recent reports evidenced that vitamin E-coated filter can be effective in protecting HD patients against OFR damage by decreasing PMN activation and providing a better control of the blood lipoperoxidation and antioxidant status, apoptosis and respiratory burst on mononuclear cells [51, 54].

In addition, it has also been proposed to lower plasma levels of $\beta_{2}$-microglobulin by changing its isoelectric point which might influence positively the elimination by dialysis [61]; to have a positive effect on uremic anemia increasing the antioxidant protection and lowering membrane peroxidation in red blood cells [62], and improve endothelial function [63].

Regarding the relationship between vitamin E-coated dialyzers (VE) and immunological status, Girndt et al. [50] have demonstrated that 4 weeks of treatment with VE or PA dialyzers enhanced in vitro proliferation on peripheral blood leukocytes (PBLs) in comparison to treatment with $\mathrm{HE}$ used before study entry. Another interesting data is that the acute production of IL-6 was reduced by VE membrane that in part results from a direct inhibitory effect on monocyte activation that is not seen with PA membrane. IL-10 is not inhibited by either membrane. VE membrane seems to have high biocompatibility, besides the parameters of complement activation and cytokine induction. However, the reduced plasma lipid peroxidation may also have a role for cytokine induction in monocytes.

Althoug PA and VE membranes have similar effects on in vitro parameters of T-cell activation during hemodialysis, these preliminary data indicate that there is an additional direct effect of vitamin E on monokine production that accounts for the reduction of the inflammatory status. In conclusion, in account of vitamin $\mathrm{E}$ bound to membrane surface, it displays both biocompatibility and bioactive characteristics that make it better than conventional cellulase membranes.
760

Nephron 2002;92:758-762
Senatore/Cecere/Colombo/Costantini/ Filiberti/Piccini/Peona/Buemi/Nicoletti/ Rizzuto 


\section{Conclusions}

In uremic patients, affected cytokine network presents a multifactorial genesis; therapeutic interventions might be multiple. Likely, the most important intervention in the present future could be the modifications of dialytic membranes. Extracorporeal treatment could benefit by vitamin E-coated membrane for its decreasing the inflammatory processes and modify signalling cascades which induce proliferation, differentiation and apoptosis/cell death.

\section{References}

1 Descamps-Latscha B, Jungers P: New molecular aspects of chronic uraemia and dialysisrelated immunocompetent cell activation. Nephrol Dial Transplant 1996;11(suppl 2): S121-S124.

2 London WT, Difiglia M, Sutnick AI, Blumberg BS: An epidemic of hepatitis in a chronic hemodialysis unit. N Engl J Med 1969;281: 571-578.

3 Rautenberg P, Proppe D, Schutte A, Ullman U: Influenza subtype-specific immunoglobulin A and $\mathrm{G}$ responses after booster versus one double-dose vaccination in hemodialysis patients. Eur J Clin Microbiol Infect Dis 1989;8:897900.

4 Girndt M, Pietsch M, Kohler H: Tetanus immunization and its association to hepatitis B vaccination in patients with chronic renal failure. Am J Kidney Dis 1995;26:454-460.

5 Kreft B, Klouche M, Kreft R, Kirchner H, Sack L: Low efficiency of active immunization against diphteria in chronic hemodialysis patients. Kidney Int 1997;52:212-216.

6 Friedman EA, Beyer MM, Hirsch SR, Schiffman G: Intact antibody response to pneumococcal capsular polysaccharides in uremia and diabetes. JAMA 1980;244:2310-2311.

7 Chatenoud L, Dugas B, Beaurain G, et al: Presence of preactivated $\mathrm{T}$ cells in hemodialyzed patients: Their possible role in altered immunity. Proc Natl Acad Sci USA 1986;83:74577461.

8 Descamps-Latscha B, Chatenoud L: T cells and B cells in chronic renal failure. Semin Nephrol 1996;16:138-191.

9 Descamps-Latscha B: The immune system in end-stage renal disease. Curr Opin Nephrol Hypertens 1993;2:883-891.

10 Pillion G, Chiesa M, Maisin A, Schlegel N Noirat C: Immunogenicity of hepatitis B vaccine (HEVAC B) in children with advanced renal failure. Pediatr Nephrol 1990;4:627629

11 Mege JL, Capo C, Purgus R, Olmer M: Monocyte production of transforming growth factor $\beta$ in long term hemodialysis: Modulation by hemodialysis membranes. Am J Kidney Dis 1996;28:395-399.

12 Mosmann TR, Cherrwinski H, Bond MW, Giedlin MA, Coffman RL: Two types of murine helper T cell clones. I. Definition according to profiles of lymphokine activities and secreted proteins. J Immunol 1986;136:23482357
13 Parronchi PD, Mancia MP, Piccini MP, Biswas $\mathrm{P}$, Simonelli $\mathrm{C}$, Maggi E, Ricci M, Anari AA, Romagnini S: Allergen- and bacterial antigen-specific T-cell clones established from atopic donors show a different profile of cytokine production. Proc Natl Acad USA 1991;88: 4538-4542.

14 Powrie F, Coffman RL: Cytokine regulation of T-cell function: Potential for therapeutic intervention. Immunol Today 1993;14:270-274.

15 Mosmann TR, Coffman RL: Th1 and Th2 cells: Different patterns of lymphokine secretion lead to different functional properties. Annu Rev Immunol 1989; 7:145-173.

16 Rook GAW, Hernandez-Pando R, Lightman SL: Hormones, peripherally activated prohormones and regulation of the Th1/Th2 balance. Immunol Today 1994;15:301-303.

17 Beaurain G, Naret C, Marcon L, et al: In vivo T cell preactivation in chronic uremic hemodialyzed and non-hemodialyzed patients. Kidney Int 1989;36:636-644.

18 Chatenoud L, Herbelin A, Beaurain G, Descamps-Latscha B: Immune deficiency of the uremic patients. Adv Nephrol Necker Hosp 1990;19:259-274.

19 Hsfeb CS, Macatonia SE, Tripp CS, Wolf SF, O'Garra A, Murphy KM: Development of Th1 CD4+ T cells through IL-12 produced by Listeria-induced macrophages. Science 1993;260: 547-549.

20 Sester U, Sester M, Hauk M, Kaul H, Kohler $\mathrm{H}$, Girndt M: T-cell activation follows Th1 rather than Th2 pattern in hemodialysis patients. Nephrol Dial Transplant 2000;15:12171223.

21 Greenfield EA, Nguyen KA, Kuchroo VK: CD28/B7 costimulation: A review. Crit Rev Immunol 1998;18:389-418.

22 Williams TM, Moolten DM, Makni H, Kim HW, Kant JA, Kamoun M: CD28-stimulated IL-2 gene expression in Jurkat T cells occurs in part transcriptionally and is cyclosporine-A sensitive. J Immunol 1992;148:2609-2616.

23 Daichou Y, Kurashige S, Hashimoto S, Suzuki $\mathrm{S}$ : Characteristic cytokine products of Th1 and Th2 cells in hemodialysis patients. Nephron 1999;83:237-245.

24 Donati D, Degiannis D, Homer L, Gastaldi L, Raskova J, Raska K Jr: Immune deficiency in uremia: Interleukin-2 production and responsiveness and interleukin-2 receptor expression and release. Nephron 1991;58:268-275.
25 Lortan JE, Kiepicla P, Coovadia HM, Seedat YK: Suppressor cells assayed by numerical and functional tests in chronic renal failure. Kidney Int 1982;22:192-197.

26 Nanishi $F$, Inenaga $T$, et al: Immune alterations in hemodialyzed patients. Effect of blood transfusion on T-lymphocyte subpopulations in hemodialyzed patients. J Clin Lab Immunol 1986;19:167-174.

27 Shabtai M, Avigad I, Schachter P, Czerniak A, Judich A, Ayalon A: Analysis of peripheral blood lymphocyte cell surface density of functional and activation associated markers in young and old hemodialysis patients. J Urol 1993;150:1369-1374.

28 Chida J, Sakurai S, Yoshiyama N: The effect of hemodialysis on lymphocyte subsets during dialysis. Clin Nephrol 1986;25:159-164.

29 Kurz P, Koler H, Meyer SC, Hutteroh T: Impaired cellular immune response in chronic renal failure. Kidney Int 1986;29:1209-1214.

30 Waltzer WC, Bachvaroff RJ, Raisbeck A, Egelandsdal B, Pullis C, Shen E, Rapaport TF: Immunological monitoring in patients with end-stage renal disease. J Clin Immunol 1984; 4:364-369.

31 Bendeer BC, Curtis JL, Nagel JE, Chrest FJ, Kraus ES, Briefel GR, Adler WH: Analsis of immune status of hemodialyzed adults: Association with prior transfusion. Kidney Int 1984;26:435-443.

32 Tvede N, Kappel M, Halkiar-Kristenson H, Galbo H, Pedersen BK: The effect of light, moderate and severe bicycle exercise on lymphocyte subsets, natural and lymphokine activated killer cells, lymphocyte proliferative response and interleukin 2 production. Int $\mathrm{J}$ Sports Med 1993;14:275-282.

33 Dinarello CA: Cytokines: Agents provocateurs in hemodialysis? Kidney Int 1992;41:683694.

34 Chopra RJ, Powers DR, Kendig NE, Adler WH, Nagel JE: Soluble interleukin 2 receptors released from mitogen-stimulated human peripheral blood lymphocytes bind interleukin 2 and inhibit IL-2 dependent cell proliferation. Immunol Invest 1989;18:961-973.

35 Clovin RB, Fuller TC, MacKeen L: Plasma interleukin-2 receptor levels in renal allograft recipients. Clin Immunol Immunopathol 1987; 43:273-276. 
36 Walz G, Kunzendorf U, Josimovic-Alasevic O, Preushoff L, Schwarz A, Keller F, Asmus G, Offerman G, Diamantstein T, Distler A: Soluble interleukin 2 receptor and tissue polypeptide antigen serum concentration in end-stage renal failure. Nephron 1990;56:157-161.

37 Rubin LA, Nelson DL: The soluble interleukin 2 receptor: Biology, function and clinical application. Ann Intern Med 1990;113:619-627.

38 Rubin LA, Jay G, Nelson DL: The released interleukin 2 receptor binds interleukin 2 efficiently. J Immunol 1986;137:3841-3844.

39 Morita Y, Yamamura M, Kashihara N, Makino $\mathrm{H}$ : Increased production of interleukin-10 and inflammatory cytokines in blood monocytes of hemodialysis patients. Mol Pathol Pharmacol 1997;98:19-33.

40 Hayakawa M, Hatano T, Sunabe T, Higa I, Osawa A: Cytokine production and cytotoxicity of lymphocytes in patients on maintenance short- or long-term hemodialysis. Nephrol Dial Transplant 1994;9:655-661.

41 Melchers IKF, Eichmann K: Quantitative studies on $\mathrm{T}$ cell diversity: Limiting dilution analysis of precursor cells for $\mathrm{T}$ helper cells reactive to xenogenic erythrocytes. J Exp Med 1982;156:1587-1603.

42 Donnely RP, Freeman SL, Hayes MP: Inhibition of IL-10 expression by IFN- $\gamma$ upregulates transcription of TNF- $\alpha$ in human monocytes. J Immunol 1995;155:1420-1427.

43 Fiorentino DF, Bond MW, Mosmann TR: Two types of mouse T helper cell. Th2 clones secrete a factor that inhibits cytokine production by Th1 clones. J Exp Med 1989;170:2081-2095.

44 Daniel V, Trautmann Y, Konrad M, Nayir A Scharer K: T-lymphocyte populations, cytokines and other growth factors in serum and urine of children with idiopathic nephritic syndrome. Clin Nephrol 1997;47:289-297.

45 Tripp CS, Wolf SF, Unanue ER: Interleukin 12 and tumor necrosis factor are costimulators of interferon $\gamma$ production by natural killer cells in severe combined immunodeficiency mice with listeriosis, and interleukin 10 is a physiologic antagonist. Proc Natl Acad Sci USA 1993;90 3725-3729.
46 Okamura $\mathrm{H}$, Tsutsui $\mathrm{H}$, et al: Cloning of a new cytokine that induces IFN- $\gamma$ production by $\mathrm{T}$ cells. Nature 1995;378:88-91

47 Eszter N, Buhlmann JE, Henics T, Waugh M, Rigby WFC: Selective modulation of IFN- $\gamma$ mRNA stability by IL-12/NKSF. Cell Immunol 1994;159:140-151.

48 Nockher WA, Soberberich JE: Expanded CD14+ CD16+ monocyte subpopulation in patients with acute and chronic infections undergoing hemodialysis. Infect Immun 1998;66: 2782-2790.

49 Girndt M, Kohler M, Schiedheim WE, Schlaak IF, et al: Production of interleukin-6, tumor necrosis factor alpha and interleukin-10 in vitro correlates with the clinical immune deficit in chronic hemodialysis patients. Kidney Int 1995;47:559-565.

50 Girndt M, Lengler S, Kaul H, Sester U, Sester M, Kohler H: Prospective crossover trial of the influence of vitamin $\mathrm{E}$ coated dialyzer membranes on T-cell activation and cytokine induction. Am J Kidney Dis 2000;35/1:95-104.

51 Galli F, Rovidati S, Chiarantini L, Campus G, Canestrari F, Buoncristiani U: Bioreactivity and biocompatibility of a vitamin E-modified multilayer hemodialysis filter. Kidney Int 1998;54:580-589.

52 Cristol JP, Canaud B, Rabedandratana H, Gailard I, Serre A, Mion C: Enhancement of reactive oxygen species production and cell surface markers expression due to hemodialys. Nephrol Dial Transplant 1994;9:389-394.

53 Rice-Evans CA, Diplock AT: Current status of antioxidant therapy. Tree Radic Biol Med 1993;15:77-96.

54 Betz M, Haensch GM, Rauterberg EW, Bommer J, Ritz E: Cuprammonium membranes stimulate interleukin-1 release and arachidonic acid metabolism monocytes in the absence of complement. Kidney Int 1988;34:67-73.
55 Schindler R, Lennemann G, Shaldon S, Koch KM, Dinarello CA: Transcription, not synthesis of interleukin-1 and tumor necrosis factor by complement. Kidney Int 1990;37:85-93.

56 Hansch GM, Seitz M, Betz M: Effect of late complement components $\mathrm{C} 5 \mathrm{~b}-9$ on human monocytes: Release of prostanoids, oxygen radicals and a factor inducing cell proliferation. Int Arch Allergy Appl Immunol 1987;82:317-320.

57 Pertosa G, Gesualdo L, Bottalico D, Schena FP: Endotoxins modulate chronically tumor necrosis factor alpha and interleukin 6 release by uraemic monocytes. Nephrol Dial Transplant 1995;10:328-333.

58 Buoncristiani U, Galli F, Rodivati S, Albertini MC, Campus G, Canestrari F: Oxidative damage during hemodialysis using a vitamin-Emodified dialysis membrane: A preliminary characterization. Nephron 1997;77:57-61.

59 Machlin LJ: Use and safety of elevated dosages of vitamin $\mathrm{E}$ in adults. Int $\mathrm{J}$ Vitamin Nutr Res Suppl 1989;30:56-58.

60 Tielemans CL, Delville JPC, Husson CP, Madhoun P, Lambrechts AM, Goldman M, Vanherweghem JL: Adhesion molecules and leukocytes common antigen on monocytes and granulocytes during hemodialysis. Clin Nephrol 1993;39:158-165.

61 Brancaccio D, Bellotti U, Lasi B, Padovese P, Cozzolino M, Carpani P, Mangione P, Giorgetti S, Gallieni M: Effects of a vitamin E-modified dialyzer on beta-2-microglobulin structure and removal. Contrib Nephrol. Basel, Karger, 1999, vol 127, pp 147-155.

62 Bonnefont-Rousselot D, Lehamann E, Jaudon MC, Delatore J, Perrone B, Reehke JP: Blood oxidative stress and lipoprotein oxidizability in hemodialysis patients: Effect of the use of a vitamin E-coated dialysis membrane. Nephrol Dial Transplant 2000; 15:2020-2028.

63 Miyazaki $H$, Matsuoka $H$, et al: Hemodialysis impairs endothelial function via oxidative stress: Effects of vitamin E-coated dialyzer. Circulation 2000;101:1002-1006. 